\title{
Utilization and Impacts of Biotechnology on Phytoremediation processes and Biodiversity conservation
}

\author{
K. Karthik, P. S. Sharavanan* \\ Department of Botany,Annamalai University, Annamalai Nagar, Tamil Nadu. \\ *E-mail address: drpssharavanan@yahoo.co.in
}

Keywords: Genetic system; Agronomic performance; Re-habitation; Phytoremediation

\begin{abstract}
Biotechnology is fast emerging globally as a very dominant economic sector. And any technological application that uses biological systems, living organisms or derivatives there to make or modify products or processes for specific importance. The present study of investigation is based on application of biotechnology may help full to develop biodiversity level or it give adverse impacts of biotechnology application of biodiversity loss.
\end{abstract}

\section{INTRODUCTION}

Biodiversity is generally considered to organisms found within the living world. In reality biodiversity is a very important and complex concept. It is deep extend into all spheres of human life and activity. And normally treated in terms of genes, species, and ecosystems in correspondence with the three fundamental hierarchical levels of biological organization. And the diversity is different level in the form of genetic diversity, species diversity and ecosystem diversity. The fourth form of biodiversity called land scape diversity, land scape is a heterogeneous land area composed of a cluster of interacting ecosystems that is repeated similar form. In biotechnology play an important role in conserving biodiversity in the form of ex-situ situations and provides new opportunities and bases for new class of non-living collections of living organism in the form of DAN libraries. The DNA, genomic and sequence data bases has been made possible. In utilization point of view biotechnology provide lot of advantages for conservation of endangered animals and plants but application of biotechnology gives adverse impacts of biodiversity in the form of processes.

\section{UTILIZATION OF BIODIVERSITY}

\section{Transgenic organisms:}

The biotechnology tools of molecular techniques provide different level of transgenic plants and animals may used as source of human conception (proteins, insulin, antibodies, lipids, fatty acids, carbohydrates and increasing the production of secondary metabolites that are used for pharmaceuticals, food additives, colorants, production of bio-pesticides.

\section{Plant breeding:}

In agronomic biodiversity is currently developed based on processes of biotechnology performance and application of genetic engineering for the production of organisms can be targeted to specific end uses and enhancing agronomic performance in yield, diseases resistance, stress tolerance. It is improved yield for both qualitative and quantitative.

\section{Ecofriendly technology:}

It is working as an environmentally friendly technology for identification of soil microbes used to translocation of metal accumulated plants through DNA fingerprinting, these are elite with reference to nitrogen fixation, phosphate solubilization, mineral leaching and phytoremediation technology. 


\section{ENVIRONMENTAL CLEAN OF PHYTOREMEDIATION TECHNOLOGY}

The important role of biotechnology play utilization of biodiversity point of view is genetic characterization of plants and microbes for developing and improving reforestation of degraded lands. The phytoremediation technology is working in symbiotic relationship between genetic characterizations of endo, ecto mycorrhizae fungi which may important as functioning of reforestation and phytoremediation.

\section{Phytoremediation:}

Phytoremediation is the use of plants to clean up environmental pollution. However, detoxification of organic pollutants by plants is often slow, leading to the accumulation of toxic compounds that could be later released into the environment.

Processes of Phytoremediation with help of Biotechnology:

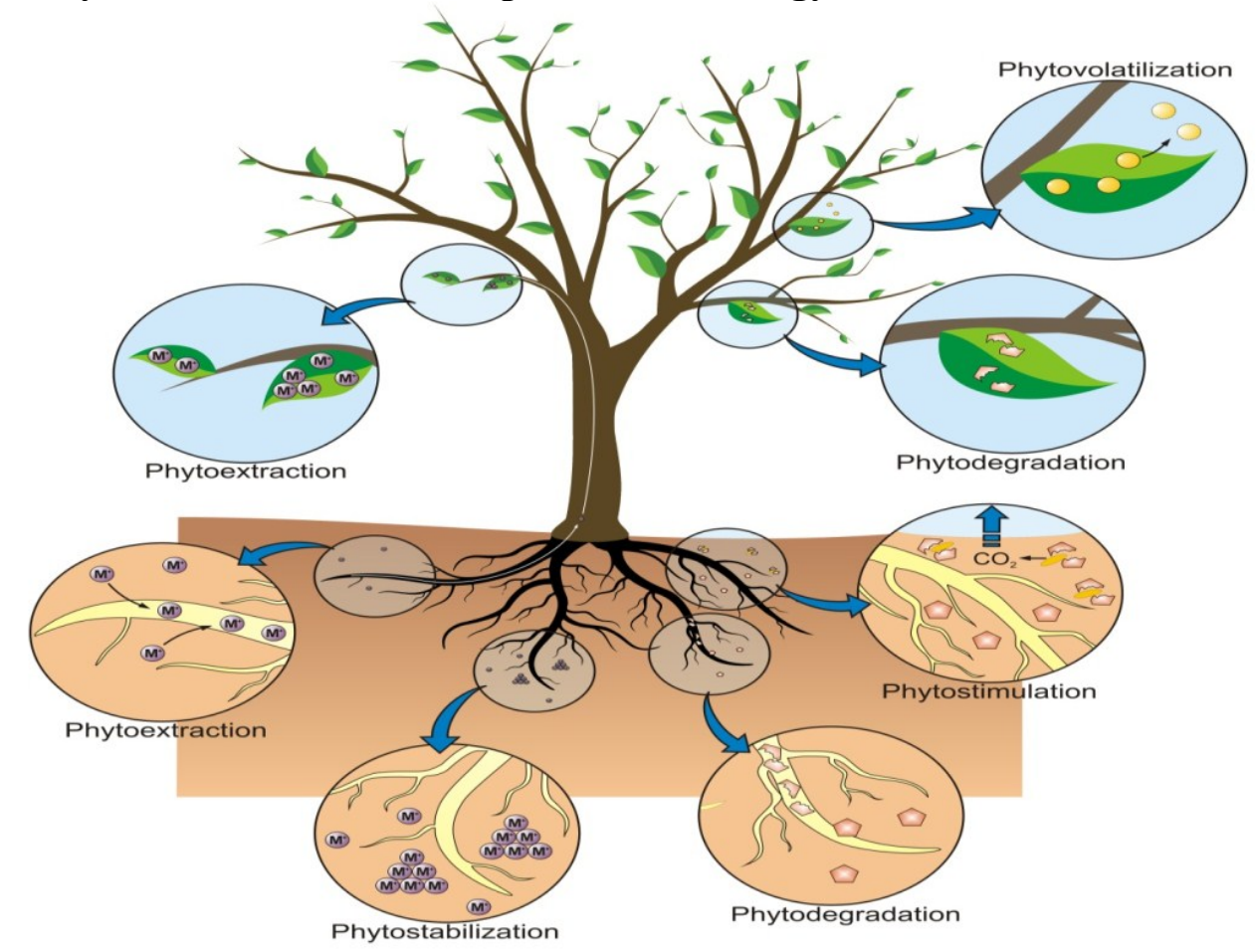

\section{MECHANISMS OF PHYTOREMEDIATION}

\section{Adverse impacts:}

The biotechnology provides lot of advantages in biodiversity and ecosystem balance in a way of currently developed bioremediation, phytoremediation technology but it gives some adverse impacts on ecosystem. There are two types of adverse impacts like direct and indirect impacts giving several non target, beneficial plants, insects are killed the Bt toxicity of crystal proteins produced from $\mathrm{Bt}$ cotton of biotechnological invention. It is a result of non target effects on beneficial one and affects to non-target organisms. It gives indirect impacts on economically high cost of biotechnological products and derived items.

\section{CONCLUSION}

The population is exponentially increasing is one of the biggest disadvantages for both economically as well as ecosystem disasters. The result of over population is depletion of biodiversity in each level of living being. And present strategy of industrialization is grown among the globe and developed into economically for the production of various kinds of industrial products. At the same time lose our earth- ecosystem for high concentration of heavy metals usage .The biotechnology is ratify and working as a greater performance of biodiversity conservation as well as environmental clean-up for developed phytoremediation processes. It is only possible, if biotechnologists, ecologists and taxonomist work in harmony. 


\section{References:}

[1] Akeroyd,J and Synge,H. 1992. Higher plant diversity.In groombridge, B(Ed) Global Biodiversity status of the earth's living resources, chapman \& Hall,London,PP.64-87.

[2] lcorn, J.B.1984. Huastec mayan ethnobotany,Univ, Texas press, Austin,Tx,PP.53-59.

[3] Aldred, J.1994. Existence value, welfare and altruism.Environ.values 2 : PP.381-402.

[4] Bisby, F.A.1994. Global master species data base and biodiversity.Biol.Inter. 29:PP.33-40.

[5] Brink, K.H. 1993. The coastal ocean process( Co op) effort.Oceanus . 36: PP.47-49.

[6] Brown,J.S.1996.Restoration ecology: living with the prine directive.In: Bowles, M.L. and whelan, C.J. (Eds.) Restoration of endangered species.Cambridge Univ.Press, PP.355-380.

[7] Chopra, K. 1993. The value of non-timber forest products: an estimate from India. Econ.Bot. 4: PP251-257.

[8] Drury ,W. H. 1974. Rare species.Biol. Conser. 6 : PP.162-169.

[9] Jones,T and Cook, M.A. 1993. Proceeding first Bio net international consultation. CAB International, London.

[10] Manilal, K.S. 1997.Taxonomy and teaching in university, Colleges in India. Rheedea 7: PP.5153. 